\title{
Ecological resistance to the invasion of a freshwater clam, Corbicula fluminea: fish predation effects
}

\author{
James V. Robinson and Gary A. Wellborn* \\ Department of Biology, The University of Texas at Arlington, Arlington, TX 76019, USA
}

\begin{abstract}
Summary. Fish predation is shown to have a twenty nine fold effect on the abundance of the invasive freshwater clam, Corbicula fluminea, in a Texas reservoir. This predation has prevented the clam from establishing the high densities commonly reported for it elsewhere. The high magnitude of the fish effect is attributed to Corbicula being an invader to this reservoir and not being able to cope well with the mix of resident fish species. In the absence of fish, colonization of the reservoir by Corbicula is spatially patchy. When fish interact with these clams, they remove sufficient numbers of individuals from dense patches to create the appearance of a spatially uniform distribution.
\end{abstract}

Key words: Corbicula fluminea - Fish predation - Invasion - Colonization - Freshwater communities

Corbicula fluminea is a freshwater clam, indigenous to Southeast Asia, which has successfully invaded many North American habitats where it often developes population densities greater than 1000 clams $/ \mathrm{m}^{2}$ (McMahon 1983). It has become widely established in north Texas during the past 20 years, but as recently as 1977 was not sampled from Fairfield Reservoir, Freestone County, Texas (Oliphint 1977). Since 1977 low densities of these clams have become established in this reservoir. Because Corbicula are highly fecund (estimates range from 8000 to 69000 juveniles/individual/year; Heinsohn 1958; Aldrige and McMahon 1978) these low densities reflect hindrance by the physical or biological environment. This research evaluates whether fish predation may be significantly resisting the invasion of this species in this reservoir.

Fish predation has been shown to affect many facets of freshwater communities including: the relative abundance patterns of aquatic insects (Hall et al. 1970; Crowder and Cooper 1982; Bohanan and Johnson 1983; Morin $1984 \mathrm{a}, \mathrm{b}$ ) and plankton (Hall et al. 1970; Zaret 1980), the structure of aquatic food webs (Gilinsky 1984), the intrapond and interpond distribution of insects (Wilson 1917; Kime 1974; von Ende 1979; Johnson and Crowley 1980; Cooper 1984) and the behavior of aquatic prey (Stein and Magnuson 1976; Williams and Moore 1982; Werner et al.

\footnotetext{
* Present address: Department of Biology, University of Michigan, Ann Arbor, Mi, 48109, USA

Offprint requests to: J.V. Robinson
}

1983). No experimental data exist regarding fish effects on freshwater bivalves.

The potential for significant fish effects on Corbicula has been alluded to by several researchers (Richardson et al. 1970; Rinne 1974; Dreier 1977; Morton 1979). Stomach content analyses indicate that the following fish have eaten Corbicula: carp, Cyprinus carpio (Sinclair and Isom 1963; Rinne 1974; Dreier 1977); smallmouth buffalo, Ictiobus bubalus (Minckley et al.1970; Rinne 1974); black buffalo, I. $n$ iger (Minckley et al. 1970; Rinne 1974); warmouth, Lepomis gulosus (Turner 1966); bluegill, L. macrochirus (Turner 1966); redear sunfish, L. microlopus (Sinclair and Isom 1963; Britton and Murphy 1977); freshwater drum, Aplodinotus grunniens (Sinclair and Isom 1963; Britton and Murphy 1966; Dreier 1977); American shad, Alosa sapidissima (Stevens 1966a); striped bass, Roccus saxatilis (Stevens 1966 b); river redhorse, Moxostoma carinatum (Hackney et al. 1970); channel catfish, Ictalurus punctatus (Sinclair and Isom 1963); blue catfish, I. furcatus (Sinclair and Isom 1963; Grantham 1967); and sturgeon, Acipenser sp. (Ingram 1959).

Many researchers have suggested that ecological communities differentially resist invasion (Elton 1958; Robinson and Valentine 1979; Roughgarden 1979; Robinson and Dickerson 1984; Diamond and Case 1986). Relevant data have been used primarily to determine if this resistance can be ascribed to competition (Nevo et al. 1972; Crowell 1973; Levins and Heatwole 1973; Cole 1983; McLachlan 1985; Moulton and Pimm 1986); however, predation may also be significant (von Ende 1979). The biota of Fairfield Reservoir includes several fish species which have been reported to have eaten Corbicula in other habitats (Table 1) and a very sparse molluscan fauna (Oliphint 1977; Wellborn and Robinson, unpublished work); this is consistent with the hypothesis that fish predation may be a constraining factor preventing this invader from establishing high population density.

If predation is important, Corbicula may have historically evolved predator avoidance mechanisms to reduce its susceptibility. Burrowing is likely to reduce predation (Edmunds 1974) as well as provide other advantages to Corbicula (e.g., it might minimize undesired movement in times of flood). Sih (1987) states that adopting a "coexisting in hiding" strategy is potentially costly to prey because they may lose opportunities to feed or mate. He further suggests that many burrowing molluses may be paying this high cost of predator avoidance. It is not clear whether this price 
Table 1. List of fish species collected from Fairfield Reservoir (adapted from Hanifen 1981)

\begin{tabular}{|c|c|}
\hline Family and scientific name & Common name \\
\hline \multicolumn{2}{|l|}{ Lepisosteidae } \\
\hline Lepisosteus oculatus (Winchell) & Spotted Gar \\
\hline Lepisosteus osseus (Linnaeus) & Longnose Gar \\
\hline Lepisosteus spatula Lacepède & Alligator Gar \\
\hline \multicolumn{2}{|l|}{ Amiidae } \\
\hline Amia calva Linnaeus & Bowfin \\
\hline \multicolumn{2}{|l|}{ Clupeidae } \\
\hline Dorosoma cepedianum (LeSueur) & Gizzard shad \\
\hline Dorosoma petenense (Gunther) & Threadfin shad \\
\hline \multicolumn{2}{|c|}{ Esocidae } \\
\hline Esox americanus vermiculatus LeSueur & Grass pickerel \\
\hline \multicolumn{2}{|l|}{ Cyprinidae } \\
\hline * Cyprinus carpio Linnaeus & Common carp \\
\hline Notemigonus crysoleucas (Mitchill) & Golden shiner \\
\hline Notropis lutrensis (Baird and Girard) & Red shiner \\
\hline Pimephales vigilax (Baird and Girard) & Bullhead minnow \\
\hline \multicolumn{2}{|l|}{ Catostomidae } \\
\hline Carpiodes carpio (Rafinesque) & River carpsucker \\
\hline Erimyzon oblongus (Mitchill) & Creek hubsucker \\
\hline * Ictiobus bubalus (Rafinesque) & Smallmouth buffalo \\
\hline \multicolumn{2}{|l|}{ Ictaluridae } \\
\hline Ictalurus melas (Rafinesque) & Black bullhead \\
\hline Ictalurus natalis (LeSueur) & Yellow bullhead \\
\hline * Ictalurus punctatus (Rafinesque) & Channel catfish \\
\hline Noturus gyrinnus (Mitchill) & Tadpole madtom \\
\hline Pylodictis olivaris (Rafinesque) & Flathead catfish \\
\hline \multicolumn{2}{|l|}{ Cyprinodontidae } \\
\hline Fundulus notatus (Rafinesque) & Blackstripe topminnow \\
\hline \multicolumn{2}{|l|}{ Poeciliidae } \\
\hline Gambusia affinis (Baird and Girard) & Mosquitofish \\
\hline \multicolumn{2}{|l|}{ Atherinidae } \\
\hline Morone chrysops (Rafinesque) & White bass \\
\hline $\begin{array}{l}\text { Morone chrysops X } M \text {. saxatilis } \\
\text { (Walbaum) }\end{array}$ & Hybrid bass \\
\hline \multicolumn{2}{|l|}{ Centrarchidae } \\
\hline Lepomis cyanellus Rafinesque & Green sunfish \\
\hline * Lepomis gulosus (Cuvier) & Warmouth \\
\hline Lepomis humilis (Girard) & Orangespotted sunfish \\
\hline * Lepomis macrochirus Rafinesque & Bluegill \\
\hline Lepomis megalotis (Rafinesque) & Longear sunfish \\
\hline * Lepomis microlophus (Gunther) & Redear sunfĩsh \\
\hline Lepomis punctatus (Valensienciennes) & Spotted sunfish \\
\hline Micropterus salmoides (La Cepède) & Largemouth bass \\
\hline Pomoxis annularis (Rafinesque) & White crappie \\
\hline Pomoxis nigromaculatus (Le Sueur) & Black crappie \\
\hline \multicolumn{2}{|l|}{ Percidae } \\
\hline Etheostoma gracile (Girard) & Slough darter \\
\hline Percina caprodes (Rafinesque) & Logperch \\
\hline \multicolumn{2}{|l|}{ Sciacnidae } \\
\hline * Aplodinotus grunniens Rafinesque & Freshwater drum \\
\hline Sciaenops ocellatus (Linnaeus) & Red drum \\
\hline \multicolumn{2}{|l|}{ Cichlidae } \\
\hline Tilapia aurea (Steindachner) & Blue tilapia \\
\hline
\end{tabular}

* Indicates species has eaten Corbicula in other habitats

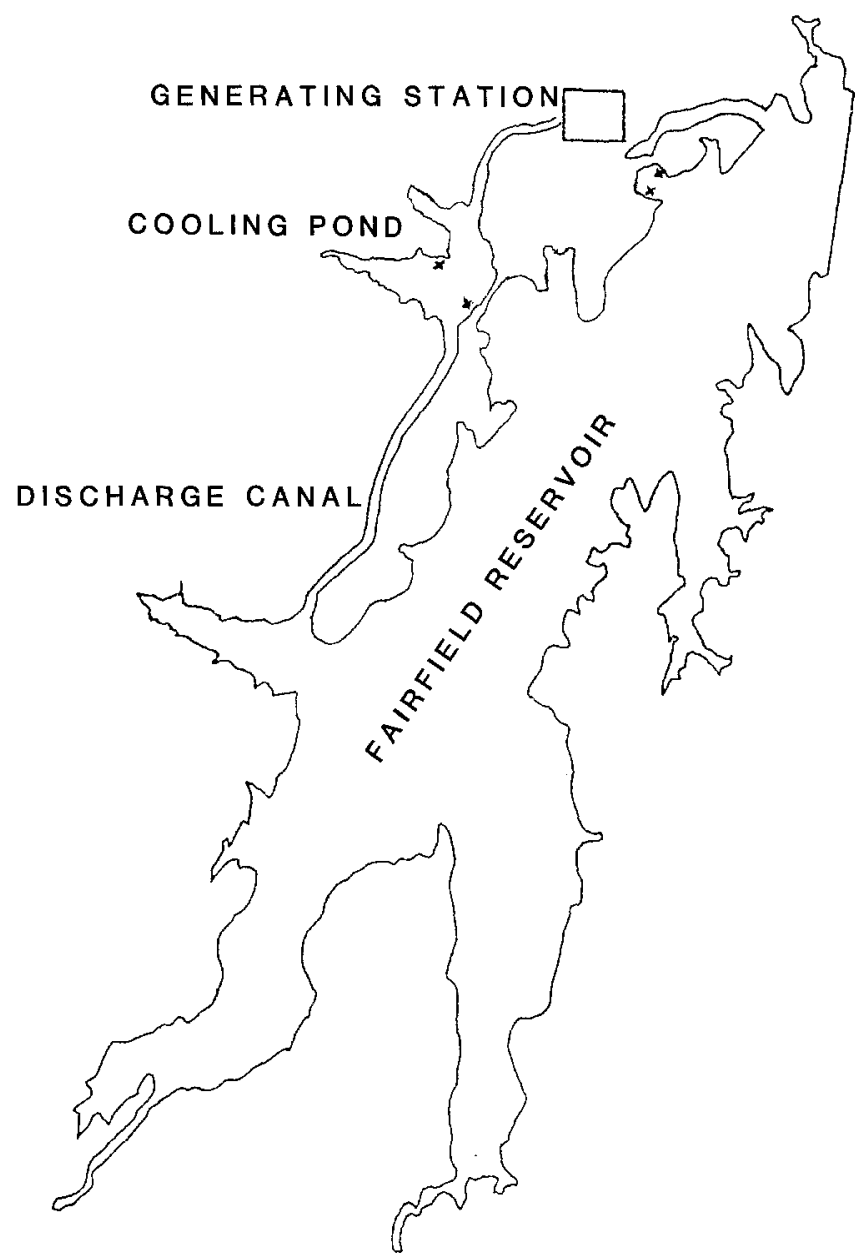

Fig. 1. Fairfield Reservoir and cooling pond. Shorelines sampled are indicated with $\mathrm{X}$ 's

is being paid by Corbicula which filter feeds while burrowed. However, if burrows constitute inferior feeding habitats, clams in burrows should grow slower than those on the surface. As part of this research, we test whether Corbicula is paying a price in terms of reduced growth (hence reduced fecundity) by burrowing rather than remaining in the sediment surface.

The main thrust of our experiment centered on determining if there was a short term direct effect of fish predation on Corbicula abundance. This was evaluated by establishing fish exclusion cages in different reservoir locations.

\section{Methods}

During January 1986 a set of 24 wood frames were established in Fairfield Reservoir. Six frames were located on each of 4 shorelines; two of these shorelines were located in a cooling pond for the Big Brown Steam Electric Generating Station while the other two were in the main section of the reservoir. The cooling pond is joined to the reservoir by a $2.5 \mathrm{KM}$ discharge canal (Fig. 1). Reservoir sites were $4 \mathrm{KM}$ north of where the canal enters the reservoir and were essentially unaffected by any thermal effluent. The 4 shorelines were chosen so that they had similar depth profiles over a $4 \mathrm{~m}$ range extending from the shore; this profile was approximately linear dropping $0.3 \mathrm{~m}$. The 
frames were paired and the members of a pair were spaced $2 \mathrm{~m}$ apart along the shoreline. Frames were constructed of $4 \times 9 \mathrm{~cm}$ pine lumber. When viewed from the top each frame was $2-4 \mathrm{~m}$ with the long axis oriented perpendicular to the shoreline. The height of the frames was $0.3 \mathrm{~m}$ nearshore and $0.6 \mathrm{~m}$ farshore. The sides of one randomly chosen member of each pair were surrounded by $1.27 \mathrm{~cm}(=0.5 \mathrm{in})$ mesh hardward cloth, leaving both top and bottom open. This mesh size is sufficiently large to permit passage of Corbicula veliger larvae which have shell lengths less than $1 \mathrm{~mm}$ (Doherty et al. 1987). The hardware cloth extended approximately $6 \mathrm{~cm}$ below the bottom frame support. All aquatic vegetation was removed from the area enclosed by the frames. To minimize between plot heterogeneity, this "vegetation-free" status was maintained throughout the duration of the experiment by the aperiodic removal of newly established vegetation.

During February 1986 a set of 54 artificial plants were added to each pen (i.e. framed area). The plants were constructed using $0.95 \mathrm{~cm}(=0.375 \mathrm{in})$ diameter, $1 \mathrm{~m}$ long steel rods. The steel rods were coated with rustproof paint. Fifteen $0.64 \mathrm{~cm}$ diameter $60 \mathrm{~cm}$ long strands of polypropylene rope were tied at their midpoints to each rod, forming a 30 strand configuration that together with the rod mimicked aquatic vegetation. The steel stems were pressed into the substrate in a uniform pattern of 9 rows of 6 plants parallel to the shoreline. This grid of plants was centered within the pen so that plants within a row were separated by a distance of $0.19 \mathrm{~m}$ and the rows were separated by $0.4 \mathrm{~m}$. These plants were used to sample plant dwelling aquatic invertebrates (Wellborn and Robinson, unpublished work), but also served to create a drag against the water that was much more substantial than the drag created by the coarse mesh of the hardware cloth (the rope surface area was over 15000 times the hardware cloth surface area). Plant dwelling aquatic macroarthropods were $11 \%$ more abundant in predator exclusion cages than in predator accessible ones (Wellborn and Robinson, unpublished work); no comparative data were obtained for nutrients or algae.

Two benthic samples were taken on each sampling date from each pen except for September when 4 samples were taken per pen. The positions of the samples were determined randomly for each date but were the same for all pens on any date. Sampling involved removing a plant and collecting samples with an Ekman grab having a sampling area of $0.0529 \mathrm{~m}^{2}$. Individuals from these samples were measured to the nearest mm.

To assess the effect of burrowing on growth the following design was used. Four hardware cloth $(0.64 \mathrm{~cm}$ mesh) enclosures $70 \mathrm{~cm}$ long, $5 \mathrm{~cm}$ wide and $15 \mathrm{~cm}$ high were divided into 12 chambers by hardware cloth panels; each chamber had dimensions $5 \times 5 \times 15 \mathrm{~cm}$. Every other vertical chamber had a hardware cloth floor inserted $5 \mathrm{~cm}$ from the top. Two of each of these enclosures were situated in one of the open pens on each shoreline studied in the main reservoir. The enclosures were buried to a depth of $10 \mathrm{~cm}$ (i.e., even with the floors). Identically sized ( + or $-0.1 \mathrm{~mm}$ ) pairs of Corbicula individuals were added to adjacent floored and unfloored chambers from above on 12 October 1986. Therefore one member of each clam pair was free to burrow while the other was constrained to the sediment surface by the floor. On 14 November 1986 the enclosures were collected and each individual was measured to the nearest tenth of a $\mathrm{mm}$.

\section{Results}

Two thousand six hundred five Corbicula individuals were collected from predator exclusion cages during this study while only 93 individuals were collected from predator accessible habitats; this corresponds to a 29:1 ratio. Both type habitats were sampled with equal intensity during six separate time intervals: 27-30 May 1986, 28-29 July 1986, 7 September 1986, 9-10 December 1986, 2-3 January 1987 (cooling pond only), and 2-3 March 1987 (main reservoir only).

Temperatures at the 2 reservoir sites were undistinguishable, as they were at the 2 cooling pond sites. The cooling pond sites were significantly warmer $(P<0.01)$ than reservoir sites. This temperature difference was biologically significant, especially during summer months, when high air temperature combined with increased heated effluent (due to higher energy demands placed on the electrical generator) sufficiently raised the cooling pond temperatures to a point (42 $\mathrm{C}$ maximum) which killed all resident macroinvertebrates. No live Corbicula were observed in the cooling ponds during July or September sampling, and greatly reduced numbers were found in December and January. Because of this, abundance patterns were analyzed separately for the cooling pond and main reservoir (Table 2).

The experimental design employed was a replicated (i.e., separate Ekman grabs) randomized complete block ANOVA. Blocks consisted of the paired frames, and accessibility to predators constituted the treatment. The results of this analysis are presented in Table 3 . The effect of predation in the main reservoir can only be understood in the context of its interaction with site for the first 4 sampling periods; no significant interaction between site and predation occured in March 1987 but at this time there was a significant effect of predation alone. In the cooling pond, a significant interaction exists between predation and site in the May sample which was taken prior to the extreme summer temperature increase. The December sample which was taken after the temperature in the cooling pond had dropped below $30 \mathrm{C}$ had a significant site effect but insignificant predation and interaction effects. By January, a significant interaction between predation and site once more existed in the cooling pond.

Ecological insight can be gained by further consideration of the interactions between predation and site. Sokal and Rohlf (1981; page 329) state that reporting the individual effects of factors has little value if a significant interaction exists between them. The abundances of these clams in these pens are primarily the result of dispersal of young and their subsequent survival. For predation to exert an important effect, clams must first colonize the sites. If the abundances of colonizing clams are significantly different between sites and fish remove most of the clams accessible to them, then the ANOVAs performed would be expected to indicate a significant predator $X$ site interaction. The hypothesis of uneven colonization among sites was tested by performing a one way ANOVA on the abundances of clams in predator exclusion cages (Table 4). This indicates that when predators are excluded, colonization (i.e. abundances) of clams is very site dependent on all sampling dates except March 1987. When a similar analysis is performed on abundances in predator accessible frames, no significant effect of sites exists. These results indicate that dispersal and subsequent establishment of Corbicula in the 
Table 2. The average number of Corbicula per Ekman Grab collected in each experimental pen at each site on each sampling date

\begin{tabular}{|c|c|c|c|c|c|c|c|c|c|c|c|c|c|}
\hline \multirow[t]{3}{*}{ Dates } & & \multicolumn{12}{|c|}{ Main Reservoir } \\
\hline & & \multicolumn{6}{|c|}{$\begin{array}{l}\text { Open pens } \\
\text { sites }\end{array}$} & \multicolumn{6}{|c|}{$\begin{array}{l}\text { Closed pens } \\
\text { sites }\end{array}$} \\
\hline & & 1 & 2 & 3 & 4 & 5 & 6 & 1 & 2 & 3 & 4 & 5 & 6 \\
\hline May & 1986 & 0.0 & 0.0 & 0.0 & 1.0 & 1.5 & 1.0 & 3.5 & 1.0 & 19.0 & 1.0 & 71.0 & 246.5 \\
\hline July & 1986 & 0.5 & 1.5 & 0.0 & 1.5 & 0.0 & 1.0 & 0.5 & 4.5 & 12.5 & 0.0 & 87.5 & 10.0 \\
\hline Sept & 1986 & 1.0 & 1.0 & 0.0 & 1.0 & 2.0 & 1.0 & 6.5 & 5.0 & 9.0 & 8.5 & 56.0 & 50.5 \\
\hline Dec & 1986 & 0.5 & 0.5 & 0.5 & 1.0 & 1.5 & 0.5 & 6.0 & 8.5 & 10.5 & 3.5 & 93.0 & 0.0 \\
\hline Jan & 1987 & - & - & - & - & - & - & - & - & - & - & - & - \\
\hline Mar & 1987 & 1.0 & 0.5 & 0.5 & 0.0 & 2.0 & 0.5 & 1.0 & 6.0 & 6.0 & 1.0 & 29.5 & 32.5 \\
\hline \multirow[t]{3}{*}{ Dates } & & \multicolumn{12}{|c|}{ Cooling pond } \\
\hline & & \multicolumn{6}{|c|}{$\begin{array}{l}\text { Open pens } \\
\text { sites }\end{array}$} & \multicolumn{6}{|c|}{$\begin{array}{l}\text { Closed pens } \\
\text { sites }\end{array}$} \\
\hline & & 7 & 8 & 9 & 10 & 11 & 12 & 7 & 8 & 9 & 10 & 11 & 12 \\
\hline May & 1986 & 2.0 & 1.5 & 1.0 & 1.0 & 2.0 & 3.0 & 19.5 & 17.0 & 34.0 & 41.5 & 118.5 & 63.0 \\
\hline July & 1986 & - & - & - & - & - & - & - & - & - & - & - & - \\
\hline Sept & 1986 & - & - & - & - & - & - & - & - & - & - & - & - \\
\hline Dec & 1986 & 0.0 & 0.0 & 0.0 & 0.5 & 2.0 & 2.5 & 0.0 & 0.0 & 0.0 & 0.0 & 1.0 & 10.5 \\
\hline Jan & 1987 & 0.0 & 0.0 & 0.5 & 0.0 & 1.0 & 0.0 & 0.5 & 0.0 & 0.0 & 2.5 & 0.5 & 8.5 \\
\hline Mar & 1987 & - & - & - & - & - & - & - & - & - & - & - & - \\
\hline
\end{tabular}

Table 3. Results of ANOVA's performed for different sampling dates to evaluate the effects of predator accessibility and site on Corbicula abundances. All data were transformed $\sqrt{(X+1)}$. Data are tabulated in Table 2

\begin{tabular}{|c|c|c|c|c|c|c|c|}
\hline \multirow[t]{3}{*}{ Date } & & \multicolumn{6}{|l|}{ F-values } \\
\hline & & \multicolumn{3}{|c|}{ Main Reservoir } & \multicolumn{3}{|c|}{ Cooling pond } \\
\hline & & Predation & Site & Interaction & Predation & Site & Interaction \\
\hline May & 1986 & $3.91 \mathrm{~ns}$ & $9.18 * * *$ & $8.30 * *$ & $33.40 * *$ & $5.17 * *$ & $4.47^{*}$ \\
\hline July & 1986 & $3.62 \mathrm{~ns}$ & $7.33 * *$ & $12.71 * *$ & - & - & - \\
\hline Sept & 1986 & $14.38 *$ & $9.50 * * *$ & $9.85 * *$ & - & - & - \\
\hline Dec & 1986 & $6.26 \mathrm{~ns}$ & $16.48 * * *$ & $10.68 * * *$ & $4.19 \mathrm{~ns}$ & $6.30^{* *}$ & $1.50 \mathrm{~ns}$ \\
\hline Jan & 1987 & - & - & - & $1.63 \mathrm{~ns}$ & $7.94^{* *}$ & $10.59 * * *$ \\
\hline Mar & 1987 & $7.62 *$ & $1.20 \mathrm{~ns}$ & $0.54 \mathrm{~ns}$ & - & - & - \\
\hline
\end{tabular}

* $P<0.05 ; * * P<0.01 ; * * * P<0.001$

ns $=$ not significant

Table 4. Results of ANOVA's performed for different sampling dates to evaluate the effect of site on Corbicula abundances in main reservoir closed and open pens. Data were transformed $\sqrt{(X+1)}$. Data are tabulated in Table 2

\begin{tabular}{llll}
\hline Date & \multicolumn{2}{l}{ F-values } & \\
\cline { 3 - 3 } & & Open pens & Closed pens \\
\hline May & 1986 & $1.38 \mathrm{~ns}$ & $8.85^{* *}$ \\
July & 1986 & $0.47 \mathrm{~ns}$ & $197.12^{* * * *}$ \\
Sept & 1986 & $1.10 \mathrm{~ns}$ & $11.24^{* * * *}$ \\
Dec & 1986 & $0.75 \mathrm{~ns}$ & $48.72^{* * *}$ \\
Mar & 1987 & $0.34 \mathrm{~ns}$ & $1.02 \mathrm{~ns}$ \\
\hline
\end{tabular}

** $P<0.01 ; * * * P<0.001 ; * * * * P<0.0001$

$\mathrm{ns}=$ not significant
Table5. Size distribution of clams collected from open and closed pens in the main reservoir, throughout the experiment's duration

\begin{tabular}{rlll}
\hline $\begin{array}{l}\text { Size category } \\
(\mathrm{mm})\end{array}$ & \multicolumn{2}{l}{ Number of clams } & \\
\cline { 2 - 4 } & Open pen & Closed pen & Total \\
\hline$<5$ & 12 & 656 & 668 \\
$5-9$ & 11 & 432 & 443 \\
$10-14$ & 10 & 632 & 642 \\
$>15$ & 18 & 225 & 243 \\
\hline Total & 51 & 1945 & 1996 \\
\hline
\end{tabular}

$\mathrm{G}=20.04, P<0.01$ 


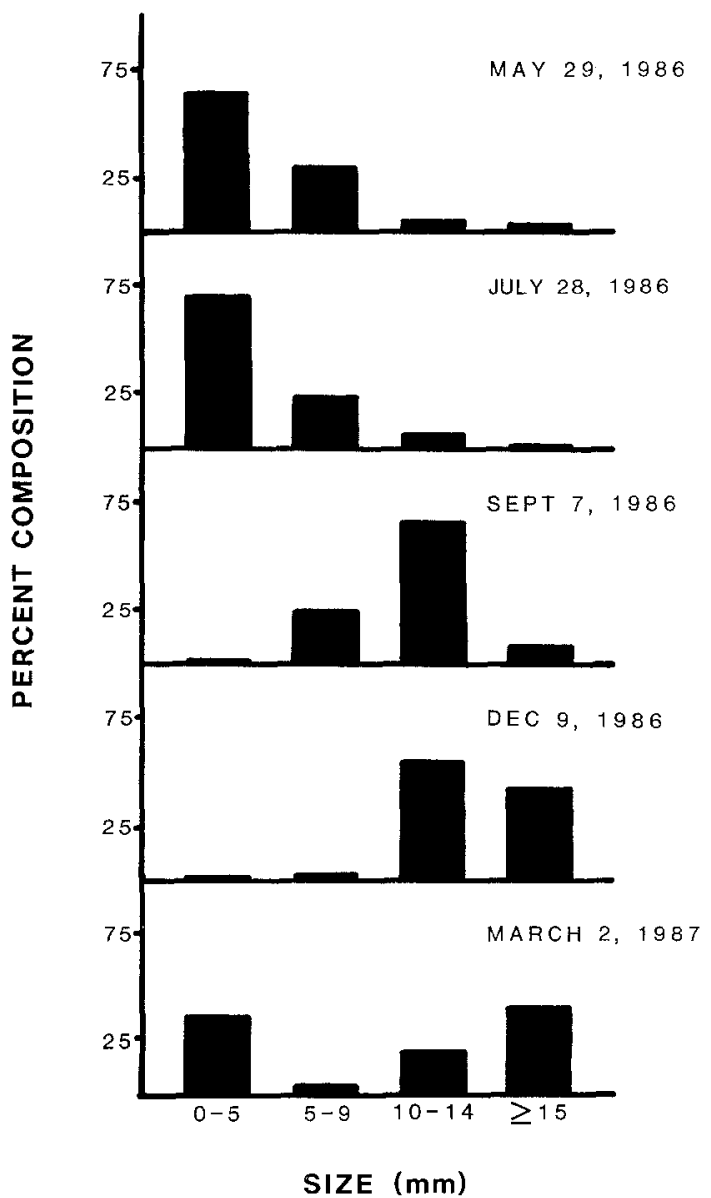

Fig. 2. Size categories of clams collected from the main reservoir during each sampling period

absence of predation is spatially patchy. Predation serves to crop individuals from abundant patches, producing the appearance of a spatially uniform dispersal pattern.

When the size pattern of main reservoir individuals collected from closed pens is compared to the pattern from open pens using a $4 \times 2$ contingency table analysis (Table 5), size pattern is shown to be dependent on predator accessibility $(\mathrm{G}=20.04, P<0.001)$. To appreciate these patterns several factors must be considered. Fairfield Reservoir reached its highest water level in recorded history between 31 May 1986 and 20 July 1986; this caused water to rise over the top of the predator exclusion pens and permitted temporary access to these pens by fish. This is responsible for fewer $5-9 \mathrm{~mm}$ individuals in July than would be expected due to normal growth of organisms in closed pens (Fig. 2). After the water receeded, the hardware cloth frames were lifted and potential contaminant fish were removed from these pens on 20 July. The elevated numbers of 10-14 mm individuals (Table 5) reflect the doubled sampling intensity in September (see Methods).

No evidence exists that this population had an autumn reproductive period as has been reported for some other populations (McMahon 1983; Doherty et al. 1987). Size patterns of individuals indicate that young clams existed abundantly during the May 1986, July 1986 and March 1987 sampling periods (Fig. 2). These data suggest that
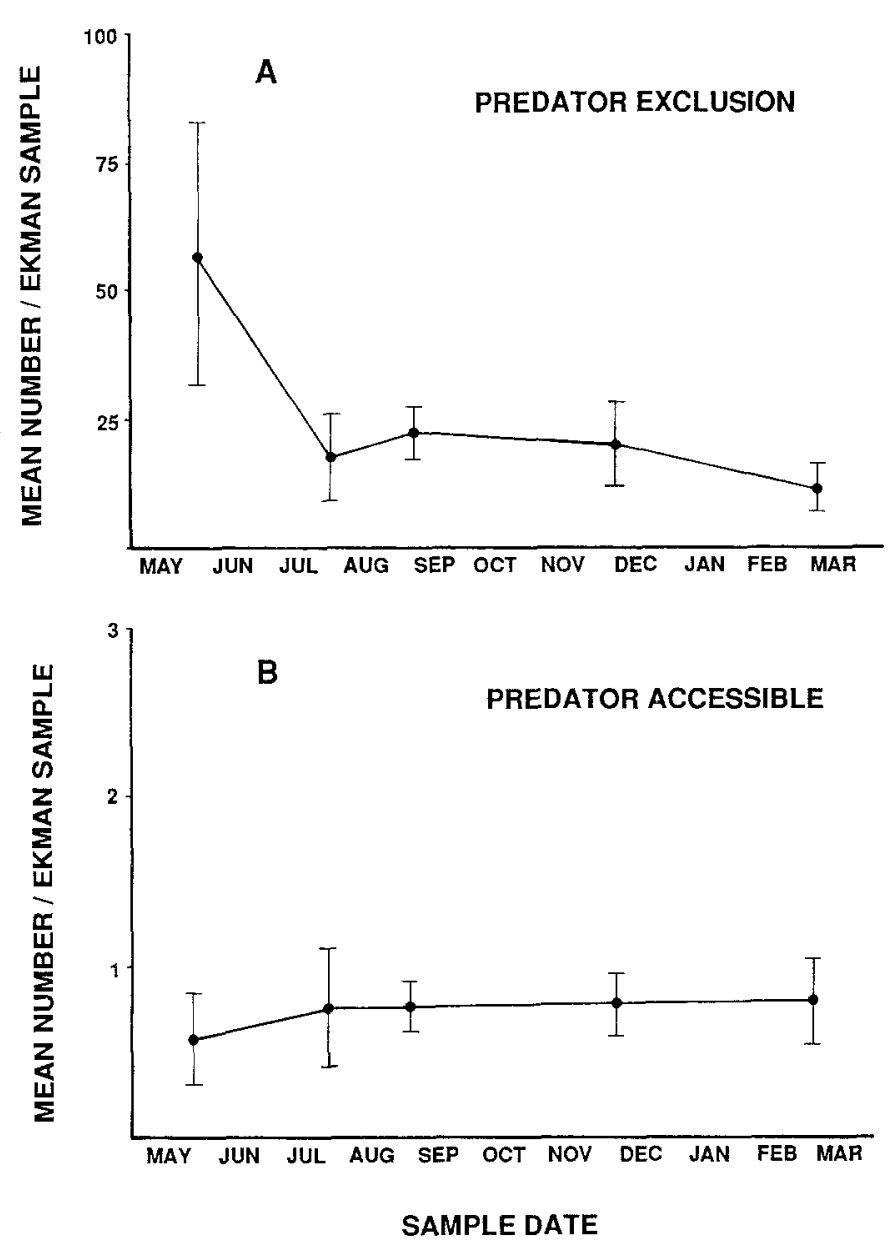

Fig. 3A, B. Abundance estimates of 1986 cohort of Corbicula individuals/grab in A predator inaccessible pens, and $\mathbf{B}$ predator accessible pens. Data are means $( \pm 1 \mathrm{SE})$

young are released throughout a period ranging from approximately March to July. When information concerning Corbicula size is included in published gut content studies it indicates that fish seem to eat small clams (e.g. $<5 \mathrm{~mm}$ Britton and Murphy 1977; predominantly 2-4 mm Grantham 1967). In the only other experimental study of predation on Corbicula, Covich et al. (1981) found that the crayfish Procambarus clarkii consumed only small clams $(<6 \mathrm{~mm})$. If only very small clams are removed by predators and survival of clams escaping predation is density independent then the ratio of clam abundances in open versus closed pens should be the same for all size categories. This does not occur (Table 5). Because of the high within date variation in Corbicula numbers per Ekman grab resulting from the between closed-site effects reported earlier, abundance estimates in closed pens on different sampling dates could not be shown to be different at a significance level greater than $P=0.0585\left(\mathrm{~F}_{\mathrm{S}(4,67)}=2.401\right)$. Figure 3 does suggest that high mortality occured in closed pens during the flood. If the anomalous post flood sample is removed, the abundance pattern for the 1986 cohort declines throughout the year in closed pens but not in open pens. This is what would be expected if there was continued density dependent mortality that was independent of predation. No such trend through time is suggested by the abundance data from predator accessible pens. These results indicate that 
the Corbicula population in Fairfield Reservoir experiences density dependent mortality when fish predation is eliminated.

The impact of burrowing was studied for 24 pairs of identically sized individuals. The shell lengths of these paired individuals ranged from 12.4 to $14.7 \mathrm{~mm}$. The differences in growth between burrowing clams and those prevented from burrowing were analyzed using a paired $t$ test. The null hypothesis that there was no difference in growth was rejected $\left(\mathrm{t}_{\mathrm{S}(23)}=2.78, P<0.05\right)$. However, our original alternative hypothesis that burrowing would be a handicap to growth (and therefore fecundity) was totally erroneous. Individuals that burrowed grew an average of $0.36 \mathrm{~mm}$ more between 12 October and 14 November than did those that remained on the surface. Those clams that burrowed increased their growth by $33 \%$.

\section{Discussion}

No fish exclusion research to date has demonstrated as large a magnitude effect of predation on macroinvertebrates as this twenty nine fold effect on Corbicula (Thorp and Bergey 1981; Flecker and Allan 1982; Flecker 1984; Gilinsky 1984; Morin 1984a; Riece and Edwards 1986). Fish eat a lot of these clams, but what is it that makes this interaction so apparently singular? Two possible explanations exist, first, Corbicula is not a member of the established community but is an invader and may be susceptible to existing predators. Second, the interactions between fish and Corbicula may be more amenable to study using fish exclusion cage methodology than would the interactions between fish and many other macroinvertebrates.

The effect of fish on macroinvertebrates can be experimentally investigated by manipulating either the fish or the invertebrates. The invasion of Corbicula into Fairfield Reservoir constitutes a natural experiment (sensu Diamond 1986) of this latter sort. When the results of natural experiments are subsequently subjected to controlled field experiments, as we have done, there is great potential for increased understanding of basic ecological phenomena (Diamond 1986).

Species distributions among many insular environments are the result of natural invasion experiments. While it is commonplace to consider invasions as either failures or successes, it is worthwhile to recognize that invasion success may be viewed quantitatively as well as qualitatively (Robinson and Dickerson 1984). Success may be measured as the persistence time of a species and persistence time is often a function of population size (MacArthur and Wilson 1967; Richter-Dyn and Goel 1972; Dickerson and Robinson 1986). Population density assessments of species in insular habitats are often reported under the rubric "population density compensation" and higher densities on islands than on continents are ascribed to reduced competition with relatively little attention given to the concomitant reduced predation (Crowell 1962; MacArthur et al. 1972; Yeaton and Cody 1973; Case 1975). These studies analyze the results of natural invasion experiments without follow up field experiments and the conclusions reported may be correct for the taxa and habitats studied. However, our research demonstrates that, for Corbicula, predation rather than competition is limiting population density in Fairfield Reservoir.

A theme emerges from field studies concerning the effect of fish predation on macroinvertebrates; significant effects are generally reported when fish are introduced into communities that are naive to fish predators (Macan 1966; Crowder and Cooper 1982) but less clearcut effects are evident when fish are excluded from communities having a history of fish predation (Thorp and Bergey 1982; Flecker and Allan 1982; Bohanan and Johnson 1983; Flecker 1984; Gilinsky 1984; NB Morin 1984a). The invasion of Corbicula represents the analogue of the former type experiment (i.e., where a potentially naive prey is added to a community that includes fish predators) and the results are comparable.

The increased susceptibility of naive prey is often reflected in their size or behavior patterns which make them obvious to fish predators (Brooks and Dodson 1965; Kime 1974; von Ende 1979; Zaret 1980). Wellborn and Robinson (1987) have demonstrated that abnormal behavior can increase the risk of predation in a dragonfly. Sih (1986) has shown that a mosquito species naive to predation by Notonecta is preyed on more frequently than an experienced species that has more finely honed antipredator behavioral responses. Yet clams have a limited behavioral repertoire, and by burrowing and remaining sessile Corbicula seems to be doing its best to avoid fish (as well as increase its growth rate). Also Corbicula is not an abnormally sized freshwater mollusc. The only unusual attribute it has is its synchronized high fecundity. This may result in enough temporally and spatially concentrated fish food to attract high densities of generalized predators.

Is this strong effect of fish in Corbicula unique to this reservoir? This can only be answered by making comparative studies in other habitats. However, McMahon (1983), while commenting on the selective value of Corbicula's life history tactics, summarizes its habitat preferences as " ... unstable sand-gravel substrata in shallow, fast flowing lotic systems, an extremely variable environment in which population densities can be reduced drastically by chance environmental factors such as flooding, periodic droughts, and subsequent aerial exposure, and temperature fluctuations, with massive mortalities as a result of both high summer temperatures and low winter temperatures." These same variable habitats are those likely to have low densities of fish. Therefore, the hypothesis that fish influence the abundance of Corbicula in habitats other than Fairfield Reservoir at least is supported circumstantially.

We have unquestionably established that fish strongly affect Corbicula abundance in our study, but why don't fish affect other macroinvertebrates as much in other studies. The answer may be due in part to the fish exclusion cage methodology. Other species (which are frequently mobile) often reproduce repeatedly and asynchronously throughout longer portions of the year than the sessile Corbicula. Therefore, if predation intensity is temporally variable in open pens, an influx of individuals can occur through immigration or reproduction following intense predation but preceeding sampling. This may minimize the apparent effect of predation. If, however, Corbicula densities are reduced from open sites this reduction would be evident in samples taken throughout the remainder of the year following the reproductive period (approximately July for this habitat).

Corbicula fluminea is of extreme economic importance to electrical generating plants and other facilities utilizing raw water. Sinclair (1971) has described Corbicula as "currently the most costly liability of all exotic molluses in North America..." The tendency of the clam to disperse 
through the water column allows it to enter industrial raw water intakes. This ability, together with rapid growth and high reproductive potential, enables Corbicula to mechanically obstruct water flow, necessitating removal procedures which often involve temporary shut-down of the facility. Our study demonstrates that fish predation may be of value in reducing the number of clams impinging on industrial facilities. As such fish may serve as a useful tool in an integrated pest management program for control of this species.

Acknowledgments. We thank Joe Sandiford and Gerry Mcllveen for assistance with construction and placement of experimental pens. J.C. Cox graciously provided assistance throughout the project. We acknowledge Richard White and the Environmental Services Division of Texas Utilities Generating Company for their support of this research. We extend a special thanks to Robert F. McMahon for providing access to his extensive library.

\section{References}

Aldridge DW, McMahon RF (1978) Growth, fecundity, and bioenergetics in a natural population of the Asiatic freshwater clam, Corbicula manilensis Philippi, from North Central Texas. J Moll Stud 44:49-70

Bohanan RE, Johnson DM (1983) Response of littoral invertebrate populations to a spring fish exclusion experiment. Freshwater Inv Bio 2: 28-40

Britton JC, Murphy CE (1977) New records and ecological notes on Corbicula manilensis in Texas. Nautilus 91:20-23

Brooks JL, Dodson SI (1965) Predation, body size, and composition of plankton. Science 150:28-35

Case TJ (1976) Species numbers, density compensation, and colonizing ability of lizards on islands in the Gulf of California. Ecology 56:3-18

Cole BJ (1983) Assembly of mangrove ant communities : colonization abilities. J Anim Ecol 52:349-355

Cooper SD (1984) The effects of trout on water striders in stream pools. Oecologia 63:376-379

Covich AP, Dye LL, and Mattice JS (1981) Crayfish predation on Corbicula under laboratory conditions. Am Midl Nat 105:181-188

Crowder LB, Cooper WE (1982) Habitat structural complexity and the interaction between bluegills and their prey. Ecology $63: 1802-1813$

Crowell K (1962) Reduced interspecific competition among the birds of Bermuda. Ecology 43:75-88

Crowell KL (1973) Experimental zoogeography: introduction of mice to small islands. Am Nat 107:535-558

Diamond J (1986) Overview: laboratory experiments, field experiments, and natural experiments. In: Diamond J, Case TJ (eds) Community Ecology. Harper and Row, New York, pp 3-22

Doherty FG, Cherry DS, Cairns J (1987) Spawning periodicity of the Asiatic Clam Corbicula fluminea in the New River, Virginia. Am Mid1 Nat 117:71-82

Diamond J, Case TJ (1986) Overview: Introductions, extinctions and invasions. In: Diamond J, Case T (eds) Community Ecology. Harper and Row, New York, pp 65-79

Dickerson JE, Robinson JV (1986) The controlled assembly of microcosmic communities: the selective extinction hypothesis. Oecologia $71: 12-17$

Dreier H (1977) Study of Corbicula in Lake Sangchris. In: The Annual Report for Fiscal Year 1976, Lake Sangchris Project Sect. 7. Illinois Natural History Survey, Urbana, pp. 7.1-7.52

Edmunds M (1974) Defense of Animals. Longman Group Limited, Essex

Elton CS (1958) The Ecology of Invasions by Animals and Plants. Chapman and Hall, London

Ende CN von (1979) Fish predation, interspecific predation, and the distribution of two Chaoborus species. Ecology 60:119-128
Flecker AS (1984) The effects of predation and detritus on the structure of a stream insect community: a field test. Oecologia 64:300-305

Flecker AS, Allan JD (1982) The importance of predation, substrate and spatial refugia in determining lotic insect distributions. Oecologia 64:306-313

Gilinsky E (1984) The role of fish predation and spatial heterogeneity in determining benthic community structure. Ecology $65: 455-468$

Grantham BJ (1967) The Asiatic clam in Mississippi. In: Proceedings of the Mississippi Water Resources Conference. Mississippi Water Resources Institute, Mississippi State University, Jackson, $p$ p $81-85$

Hackney PA, Tatum WM, Spencer SL (1970) Life history study of the River Redhorse, Moxostoma carinatum (Cope), in the Cahaba River, Alabama, with notes on the management of the species as a sport fish. J Alabama Acad Sci 40:81-89

Hall DJ, Cooper WE, Werner EE (1970) An experimental approach to the production dynamics and structure of freshwater animal communities. Limnol and Oceanogr. 15:839-928

Hanifen JG (1981) Fish populations of Fairfield Reservoir, Texas ten years after impoundment and the effects of the introduction of Tilapia aurea. MS Thesis, Texas A and M University

Heinsohn GE (1958) Life history and ecology of the freshwater clam, Corbicula fluminea. MS, University of California, Santa Barbara

Ingram WM (1959) Asiatic clams as potential pests in California water supplies. J Am Water Works Assoc 51:363-370

Johnson DM, Crowley PH (1980) Odonate "hide and seek" habitat-specific rules? In: Kerfoot WC (ed) Evolution and Ecology of Zooplankton Communities. University Press of New England, Hanover, New Hamshire, pp 569-579

Kime J (1974) Ecological relationships among three species of aeshnid dragonfly larvae. PhD Thesis, University of Washington

Levins R, Heatwole H (1973) Biogeography of the Puerto Rican bank: introduction of species onto Palominitos Island. Ecology 54:1056-1064

Macan TA (1966) The influence of predation on the fauna of a moorland fishpond. Arch Hydrobiol 61:432-452

MacArthur RH, Diamond JM, Karr JR (1972) Density compensation in island faunas. Ecology $53: 330-342$

MacArthur RH, Wilson EO (1967) The Theory of Island Biogeography. Princeton University Press, Princton, New Jersey

McLachlan AJ (1985) What determines the species present in a rainpool? Oikos 46:1-7

McMahon RF (1983) Ecology of an invasive pest bivalve, Corbicula. In: Russell-Hunter WD (ed) The Mollusca, vol 6, Ecology. Academic Press, San Diego, pp 505-561

McMahon RF, Williams CJ (1986) Growth, life cycle, upper thermal limit and downstream colonization rates in a natural population of the freshwater bivalve mollusc, Corbicula fluminea (Muller), receiving thermal effluents. Proc Int Corbicula Symposium 2:231-239

Minckley WL, Johnson JE, Rinne JN, Willoughby SE (1970) Foods of buffalofishes, genus Ictiobus, in central Arizona reservoirs. Trans Am Fish Soc 99:333-342

Morin PJ (1984a) The impact of fish exclusion on the abundance and species composition of larval odonates: results of short term experiments in a North Carolina farm pond. Ecology $65: 53-60$

Morin PJ (1984b) Odonate guild composition: experiments with colonization history and fish predation. Ecology 65:1866-1873

Morton B (1979) Freshwater fouling bivalves. Proceedings International Corbicula Symposium 1:1-14

Moulton MP, Pimm SL (1986). The extent of competition in shaping an introduced avifauna. In: Diamond J, Case TJ (eds) Community Ecology. Harper and Row, N.Y. pp 80-97

Nevo E, Gorman G, Soule M, Yung Yang S, Clover R, Jovanovic V (1972) Competitive exclusion between two insular Lacerta species. Oecologia 10:183-190

Oliphint RP (1977) Some effects of thermal effluents on the second- 
ary productivity of benthic macroinvertebrates of Fairfield Reservoir. MS. Stephen F. Austin State University

Reice SR, Edwards RL (1986) The effect of vertebrate predation on lotic macroinvertebrate communities in Quebec, Canada. Can J Zool 64:1930-1936

Richardson WM, St. Amant JA, Bottroff LJ, Barker WL (1970) Introduction of blue catfish into California. Cal Fish and Game $56: 311-312$

Richter-Dyn N, Goel NS (1972) On the extinction of a colonizing species. Theor Pop Biol 3:406-433

Rinne JN (1974) The introduced Asiatic clam, Corbicula, in Central Arizona reservoirs. Nautilus 88:56-61

Robinson JV, Dickerson JE (1984) Testing the invulnerability of laboratory island communities to invasion. Oecologia $61: 169-174$

Robinson JV, Valentine WD (1979) The concepts of elasticity, invulnerability, and invadability. J Theor Biol 81:91-104

Roughgarden J (1979) Theory of Population Genetics and Evolutionary Ecology: An Introduction. Mac Millan, New York

Sih A (1986) Antipredator responses and the perception of danger by mosquito larvae. Ecology 67:434-441

Sih A (1987) Predators and prey lifestyles: an evolutionary and ecological overview. In: Kerfoot EC, Sih A (eds) Predation: Direct and Indirect Impacts on Aquatic Communities. Univ. Press of New England, Hanover, NH, pp 203-224

Sinclair RM (1971) Annotated bibliography on the exotic bivalve Corbicula in North America, 1900-1971. Sterkiana 43:11-18

Sinclair RM, Isom BG (1963) Further studies on the introduced asiatic clam Corbicula in Tennessee. Tennessee Stream Pollution Control Board, Tennessee Department of Public Health, Nashville

Sokal RR, Rohlf FJ (1981) Biometry (second edition). W. H. Freeman, San Francisco
Stein RA, Magnuson JJ (1976) Behavioral response of crayfish to a fish predator. Ecology 57:751-761

Stevens DE (1966a) Distribution and food habits of the American shad Alosa sapidissima in the Sacramento-San Joaquin Delta. Cal Fish Game Bull 136:97-197

Stevens DE (1966b) Food of striped bass, Roccus saxatilis in the Sacramento-San Joaquin Delta. Cal Fish Game Bull 136:68-96

Thorp JH, Bergey EA (1981) Field experiments on responses of a freshwater, benthic macroinvertebrate community to vertebrate predators. Ecology 62:365-375

Turner JL (1966) Distribution and food habits of Centrarchid fishes in the Sacramento-San Joaquin Delta. Cal Fish Game Bull 136:144-153

Wellborn GA, Robinson JV (1987) Microhabitat selection as an antipredator strategy in the aquatic insect Pachydiplax longipennis Burmeister (Odonata: Libellulidae). Oecologia 71:185-189

Werner EE, Gilliam JF, Hall DJ, Mittlebach GG (1983) An experimental test of the effects of predation risk on habitat use in fish. Ecology 64:1540-1548

Williams DD, Moore KA (1982) The role of semiochemicals in benthic community relationships of the lotic amphipod $\mathrm{Gam}$ marus pseudolimnaeus: a laboratory analysis. Oikos 44:280-286

Wilson CB (1917) Dragonflies and damselflies in relation to pondfish culture, with a list of those found near Fairport, Iowa. Bull Bur Fish 36:181-266

Yeaton RI, Cody ML (1974) Competitive release in island song sparrows. Theor Pop Biol 5:42-58

Zaret TM (1980) Predation and Freshwater Communities. Yale University Pres, New Haven, London

Received February 23, 1988 